\title{
Laju Filtrasi Glomerulus pada Anak: Metode Apa yang Digunakan?
}

\author{
Nitish Basant Adnani, Sudung O. Pardede* \\ Departemen Ilmu Kesehatan Anak FKUI-RSCM Jakarta
}

\begin{abstract}
Abstrak
Laju filtrasi glomerulus (LFG) adalah kecepatan filtrasi volume plasma melalui ginjal per unit waktu per luas permukaan tubuh (LPB) dan merupakan salah satu indikator utama untuk pemantauan fungsi ginjal. Standar baku emas untuk menentukan LFG saat ini adalah dengan menghitung klirens inulin ginjal. Akan tetapi, karena prosedur tersebut dinilai kompleks, maka klirens inulin tidak digunakan dalam praktik klinik. Estimasi LFG menggunakan penanda eksogen lainnya seperti kreatinin serum dan sistatin $\mathrm{C}$ merupakan pilihan praktis yang dapat menggantikan perhitungan klirens inulin ginjal. Penentuan LFG pada anak berbeda dengan pada dewasa karena tidak mudah mengumpulkan urin per hari pada anak, sehingga diperlukan formula untuk mempermudah menentukan LFG. Berbagai peneliti telah melakukan penelitian untuk menemukan rumus untuk menentukan LFG dengan mudah dan praktis. Pemeriksaan LFG biasanya dilakukan berbasis klirens kreatinin dan belakangan ini dilakukan degan pemeriksaan sistatin C. Beberapa penanda yang digunakan untuk pengukuran LFG antara lain zat radiofarmaka seperti chromium 51-labeled ethylenediaminetetraacetic acid $\left({ }^{51} \mathrm{Cr}-\mathrm{EDTA}\right)$, technetium 99-labeled diethylenetriaminepentaacetic acid $\left.{ }^{99 \mathrm{~m}} \mathrm{Tc}-\mathrm{DTPA}\right)$, iodine 125 -labeled iothalamate $\left({ }^{125} \mathrm{I}-\right.$ iothalamate), dan zat kontras radiografik. Dari berbagai rumus estimasi LFG, salah satu yang kini direkomendasikan untuk digunakan pada praktik klinis sehari-hari adalah rumus Schwartz yang dimodifikasi, karena dinilai sederhana, relatif akurat, tidak invasif, dan tidak membutuhkan biaya yang mahal.
\end{abstract}

Kata kunci: laju filtrasi glomerulus, penyakit ginjal pada anak, kreatinin, sistatin C

\section{Glomerular Filtration Rate in Children: Which Method Should be Used?}

\begin{abstract}
Glomerular filtration rate (GFR), which represents the plasma volume filtered through the kidney for each time unit and body surface area (BSA) unit, is one of the main indicators for renal function. The current gold standard for determining GFR is by calculating the renal inulin clearance. However, because this involves a complex procedure, inulin clrearance was not used in clinical practice. GFR estimation using other exogenous markers such as serum creatinine and cystatin $\mathrm{C}$ can be considered as practical alternatives. Determining GFR in children is difference with in adult because difficulty of 24 hours urine collection in children, so iti is needed a simple formula for determining GFR. Some researchers performed studies for determining easy and practical formula. GFR examinations usually based on creatinine clearance and nowadays by cyatatin $\mathrm{C}$ examination. Some markers are used in measuring of GFR such as chromium 51-labeled ethylenediaminetetraacetic acid $\left({ }^{51} \mathrm{Cr}\right.$-EDTA), technetium 99-labeled diethylenetriaminepentaacetic acid ( $\left.{ }^{99 \mathrm{~m}} \mathrm{Tc}-\mathrm{DTPA}\right)$, iodine 125-labeled iothalamate ( ${ }^{125} \mathrm{I}$-iothalamate), and radiographic contrast. Among the various existing formulas to estimate GFR, one of the most commonly recommended in daily clinical practice is the modified Schwartz formula, as it is thought to be simple, relatively accurate, non-invasive, and inexpensive.
\end{abstract}

Keywords: glomerular filtration rate, pediatric kidney diseases, creatinine, cystatin C

*SOP: Penulis Koresponden; E-mail: suopard@yahoo.com 


\section{Pendahuluan}

Laju filtrasi glomerulus (LFG) merupakan salah satu indikator yang terbaik untuk mendeskripsikan fungsi ginjal, memantau progresivitas penyakit ginjal, dan menentukan dosis obat yang sesuai pada pasien dengan kelainan ginjal. Laju filtrasi glomerulus menggambarkan kecepatan volume plasma yang difiltrasi oleh ginjal untuk setiap unit waktu, dan secara umum dijelaskan dalam unit milimeter per menit. Seringkali, nilai yang didapat disesuaikan berdasarkan luas permukaan badan (LPB) dan diekspresikan dalam unit milimeter per menit per $1,73 \mathrm{~m}^{2}\left(\mathrm{~mL} /\right.$ menit $\left./ 1,73 \mathrm{~m}^{2}\right){ }^{1}$

Estimasi LFG pada anak telah diteliti selama lebih dari 40 tahun terakhir, dimulai dengan publikasi oleh Schwartz dkk. pada tahun 1976 yang mengemukakan rumus sederhana, yaitu $[\mathrm{LFG}=0,55 \mathrm{x} \mathrm{T/Cr}]$, dengan T merupakan tinggi badan anak dalam sentimeter $(\mathrm{cm})$ dan $\mathrm{Cr}$ merupakan kadar kreatinin serum dalam miligram per desiliter $(\mathrm{mg} / \mathrm{dL}){ }^{2}$ Seiring dengan berjalannya waktu, konstanta 0,55 tersebut diubah menjadi 0,413 untuk anak dan remaja, yang dinilai lebih sesuai setelah dilakukan pengkajian lebih lanjut menggunakan isotope dilution mass spectroscopy (IDMS) untuk kadar kreatinin serum. ${ }^{3}$

Tinggi badan anak digunakan sebagai parameter pengganti massa otot, karena kreatinin, yang merupakan produk destruksi massa otot, dapat memiliki perubahan nilai seiring dengan bertumbuhnya anak. Rumus Schwartz telah direkomendasikan oleh Kidney Disease Improving Global Outcomes (KDIGO) untuk mengestimasi laju filtrasi glomerulus pada anak. Namun, salah satu keterbatasan rumus tersebut adalah perlunya data tinggi badan anak, yang tidak selalu tersedia di laboratorium klinis dan membuat pelaporan otomatis LFG bersama dengan kadar kreatinin serum menjadi tidak dapat dilakukan. ${ }^{4}$

Standar baku emas dalam pengukuran LFG saat ini adalah dengan menghitung klirens inulin ginjal, akan tetapi perhitungannya membutuhkan proses yang sangat kompleks. Oleh karena itu, perhitungan menggunakan penanda filtrasi eksogen lain seringkali digunakan sebagai pengganti klirens inulin untuk mengestimasi LFG secara lebih sederhana. ${ }^{5}$ Saat ini, terdapat beberapa rumus yang dapat digunakan untuk menghitung estimasi LFG dalam praktik klinis sehari-hari yang menggunakan kadar sistatin $\mathrm{C}$ atau kreatinin serum serta parameter demografis seperti tinggi badan. Namun, berbagai rumus tersebut juga memiliki keterbatasannya masing-masing. Oleh sebab itu penting untuk mengetahui keunggulan masing-masing rumus tersebut serta cara penggunaannya yang tepat.

Tujuan makalah ini adalah untuk menjelaskan pengukuran estimasi LFG pada anak serta cara mengestimasi nilai LFG pada anak untuk digunakan dalam praktik klinis sehari-hari.

\section{Laju Filtrasi Glomerulus}

Laju filtrasi glomerulus merupakan nilai yang menggambarkan kecepatan volume plasma yang melalui filtrasi di glomerulus untuk setiap unit waktu berdasarkan luas permukaan badan (LPB), dan diekspresikan dalam unit $\mathrm{mL} / \mathrm{menit} / 1,73 \mathrm{~m}^{2}$. Nilai LFG merupakan salah satu indikator utama fungsi ginjal. Proses pembentukan urin berawal dari filtrasi, yaitu proses penyaringan plasma melalui dinding kapiler glomerulus. Hasil ultrafiltrasi tersebut mengandung berbagai zat yang terdapat pada plasma, termasuk elektrolit, glukosa, ureum, kreatinin, dan protein tertentu dengan berat molekul rendah. Protein dengan berat molekul yang tinggi, seperti albumin dan globulin, tidak terfiltrasi oleh glomerulus pada keadaan normal. Setelah proses filtrasi, filtrat yang dihasilkan akan terkumpul di dalam ruang Bowman dan melalui tubulus, lalu mengalami reabsorbsi dan sekresi yang mengakibatkan perubahan komposisi sesuai kebutuhan tubuh sebelum akhirnya menjadi urin. ${ }^{6}$ 


\section{Metode Pengukuran LFG pada Anak}

Penilaian fungsi ginjal atau LFG yang ideal sebaiknya akurat, sederhana, aman, dan terjangkau. Namun, pengukuran LFG secara langsung tidak mungkin dilakukan karena proses filtrasi yang terjadi berlangsung secara simultan pada jutaan glomerulus. LFG sendiri tidak dapat diukur secara langsung, dan oleh sebab itu dilakukan pengukuran klirens penanda filtrasi yang ideal atau zat eksogen tertentu dari proses filtrasi yang berlangsung. ${ }^{7}$

Penanda filtrasi yang ideal harus memiliki karakteristik fisiologis yang ketat yakni harus difiltrasi bebas seluruhnya melalui glomerulus, tidak disekresi, tidak diabsorpsi oleh tubulus ginjal, tidak terikat pada protein plasma, tidak toksik, diekskresikan hanya oleh ginjal, mudah diukur dari plasma dan urin, terjangkau, dan tersedia di pasaran. Inulin merupakan suatu polimer fruktosa tanpa muatan listrik dengan ukuran 5.200 Dalton, yang saat ini diketahui sebagai marker filtrasi yang paling ideal untuk fungsi ginjal. Klirens inulin dari sampel plasma dan urin saat ini diketahui sebagai metode standar baku emas untuk menentukan LFG. Pengukuran klirens inulin merupakan metode standar referensi pertama yang dipakai dan perannya dalam penentuan LFG didapatkan dari rangkaian penelitian fisiologis yang telah dilakukan. Namun, terdapat keterbatasan dalam penggunaannya untuk praktik klinis seharihari, karena melibatkan prosedur yang invasif, memiliki ketersediaan yang terbatas, serta membutuhkan biaya yang tinggi. ${ }^{8}$ Oleh karena itu, dalam praktik klinis dan penelitian, klirens inulin tidak digunakan dan yang lebih sering digunakan adalah marker eksogen lainnya.

Penanda yang digunakan untuk pengukuran LFG mencakup kreatinin, sistatin C, beberapa zat radiofarmaka seperti chromium 51-labeled ethylenediaminetetraacetic acid $\left({ }^{51} \mathrm{Cr}\right.$-EDTA), technetium 99-labeled diethylenetriaminepentaacetic acid ( $\left.{ }^{99 \mathrm{~m}} \mathrm{Tc}-\mathrm{DTPA}\right)$, serta iodine 125 labeled iothalamate ( ${ }^{125} \mathrm{I}$-iothalamate), serta zat kontras radiografik, seperti ioheksol dan iotalamat. ${ }^{9}$

\section{Nilai Normal LFG pada Anak}

Pengukuran LFG secara langsung melibatkan prosedur yang kompleks dan invasif. Oleh karena itu, penelitian yang mengevaluasi pengukuran secara langsung tersebut pada anak sehat masih sangat terbatas. Menentukan rentang normal LFG pada anak membutuhkan perhitungan dengan presisi dan ketepatan yang tinggi. ${ }^{10}$ Telaah yang dilakukan oleh Schwartz dan Work $^{8}$ pada tahun 2009 mendeskripsikan rerata nilai normal LFG pada anak di atas usia 2 tahun berdasarkan klirens inulin yang dirangkum dari penelitian Brodehlet al. ${ }^{11}$ serta berdasarkan klirens ${ }^{51} \mathrm{Cr}$-EDTA plasma dari penelitian Piepsz dkk. ${ }^{12}$ Tabel 1 menunjukkan nilai LFG pada anak berdasarkan usia.

Tabel 1. Laju Filtrasi Glomerulus pada Anak dan Remaja Sehat Tanpa Kelainan Ginjal yang Dihitung Berdasarkan Klirens Inulin ${ }^{11}$

\begin{tabular}{cc}
\hline Usia (tahun) & $\begin{array}{c}\text { Laju filtrasi glomerulus (mL/menit/1,73 } \mathbf{~ m}^{\mathbf{2}} \text { ) } \\
\text { (rerata } \pm \text { standar deviasi) }\end{array}$ \\
\hline $3-4$ & $111,2 \pm 18,5$ \\
$5-6$ & $114,1 \pm 18,6$ \\
$7-8$ & $111,3 \pm 18,3$ \\
$9-10$ & $110,0 \pm 21,6$ \\
$11-12$ & $116,4 \pm 18,9$ \\
$13-15$ & $117,2 \pm 16,1$ \\
\hline
\end{tabular}

Pada Tabel 2 terlihat nilai klirens Cr EDTA pada anak normal berdasarkan usia. 
Tabel 2. Klirens ${ }^{51} \mathrm{Cr}$-EDTA Plasma pada Anak dan Remaja Normal ${ }^{12}$

\begin{tabular}{cc}
\hline Usia (tahun) & $\begin{array}{c}\text { Laju filtrasi glomerulus (mL/menit/1,73 } \mathbf{~ m}^{\mathbf{2}} \text { ) } \\
\text { (rerata } \pm \text { standar deviasi) }\end{array}$ \\
\hline$<1,2$ & $52,0 \pm 9,0$ \\
$1,2-3,6$ & $61,7 \pm 14,3$ \\
$3,6-7,9$ & $71,7 \pm 13,9$ \\
$7,9-12$ & $82,6 \pm 17,3$ \\
$12-18$ & $116,4 \pm 18,9$ \\
\hline
\end{tabular}

Perbedaan yang cukup signifikan yang diamati dari kedua tabel di atas dipikirkan terjadi akibat estimasi LFG yang terlalu rendah pada perhitungan yang menggunakan ${ }^{51} \mathrm{Cr}$-EDTA atau yang lebih memungkinkan akibat perbedaan LPB pada populasi saat ini dibandingkan dengan 30 tahun yang lalu. Salah satu telaah ilmiah menunjukkan bahwa rentang normal LFG yang dewasa ini dianut berkisar antara $100-110 \mathrm{~mL} / \mathrm{menit} / 1,73 \mathrm{~m}^{2}$, yang cenderung lebih rendah dibandingkan dengan beberapa dekade yang lalu. Penurunan tersebut diduga berkaitan dengan penyesuaian LFG terhadap LPB, karena didapatkan peningkatan LPB yang signifikan selama tiga dekade terakhir, dan nilai LFG yang tidak disesuaikan berdasarkan LPB tidak menunjukkan adanya penurunan yang besar. ${ }^{13}$

Penelitian oleh Piepsz et al. ${ }^{12}$ mencantumkan bahwa LFG meningkat secara progresif dari periode neonatal sampai usia sekitar 2 tahun, kemudian mencapai nilai yang stabil dengan rerata $107 \mathrm{~mL} / \mathrm{menit} / 1,73 \mathrm{~m}^{2}$. Namun, karena data yang dirangkum dari berbagai penelitian yang ada sebagian besar dilakukan di benua Eropa, serta mempertimbangkan bahwa data dari sebagian penelitian sudah relatif lama, masih dibutuhkan penelitian lebih lanjut untuk menentukan apakah nilai tersebut juga representatif untuk populasi anak di Indonesia.

\section{Estimasi Nilai LFG pada Anak}

Rumus untuk mengestimasi nilai LFG berdasarkan konsentrasi kreatinin atau sistatin C pada serum cukup umum digunakan baik dalam konteks klinis maupun penelitian. Upaya terus dilakukan untuk memperbaiki dan mengembangkan cara baru yang lebih baik dalam mengestimasi LFG pada anak dan remaja. Salah satu kelemahan utama beberapa rumus estimasi LFG yang ada adalah ketidaktepatan angka LFG yang didapat serta tidak adanya alternatif pengukuran LFG secara langsung dengan akurasi dan ketepatan yang sebanding. Rumus yang digunakan untuk memprediksi LFG sangat bergantung dari data yang digunakan pada saat rumus tersebut dikembangkan. Penting untuk diingat bahwa rumus yang dibuat berdasarkan data anak sehat akan berbeda dengan rumus yang dikembangkan berdasarkan data anak dengan kelainan ginjal. ${ }^{14}$

\section{Rumus LFG Berbasis Kreatinin Serum}

Kreatinin merupakan suatu derivat asam amino dengan berat molekul 113 Dalton dan difiltrasi secara sepenuhnya oleh glomerulus, yang menjadi salah satu penanda endogen LFG yang paling populer. ${ }^{15}$ Rumus LFG berbasis kreatinin serum pada anak yang pertama kali dipublikasikan dan digunakan adalah rumus Schwartz lama, yaitu $[\mathrm{LFG}=0,55 \mathrm{x} \mathrm{T} / \mathrm{Cr}$, dengan T menggambarkan tinggi badan dan $\mathrm{Cr}$ menggambarkan kadar kreatinin serum. ${ }^{2}$

Selain itu, rumus dengan kreatinin serum juga dikembangkan berdasarkan data yang dirangkum dari penelitian Pottel et al. ${ }^{10}$ dan Piepsz et al. ${ }^{12}$ yang dikenal dengan rumus Metadata Flanders, yakni $[\mathrm{LFG}=(0,0414 \times \ln ($ usia $)+0,3018) \times \mathrm{T} / \mathrm{Cr}]$. Rumus ini berbeda dengan rumus Schwartz karena mempertimbangkan konstanta yang bergantung usia. Dengan rumus Metadata Flanders, angka konstanta yang digunakan dalam mengestimasi LFG 
memiliki rentang antara 0,3018 pada usia 1 tahun sampai sekitar 0,413 pada usia 15 tahun, yang mengindikasikan bahwa konstanta 0,413 yang dipakai pada rumus Schwartz yang dimodifikasi dapat cenderung lebih tinggi untuk sebagian besar anak sehat. Namun, sangat penting untuk mempertimbangkan bahwa rumus Schwartz yang dimodifikasi dikembangkan dari penelitian yang melibatkan 349 anak berusia 1 hingga 16 tahun dengan kelainan ginjal yang telah terkonfirmasi (dengan median LFG dari ioheksol sebesar 41,3 mL/menit/1,73 $\mathrm{m}^{2}$ ), sedangkan rumus Metadata Flanders disusun berdasarkan data yang didapat dari populasi anak sehat. ${ }^{1}$

Penelitian oleh Pottel et al. ${ }^{16}$ pada tahun 2012 mengaplikasikan perhitungan LFG pada anak berdasarkan usia. Penelitian ini merangkum nilai median kreatinin serum $\left(\mathrm{Cr}_{50}\right)$ untuk masing-masing usia dalam bentuk tabel dengan data yang ternormalisasi, dan mengajukan perhitungan dengan menggunakan rumus $\left[\mathrm{LFG}=107,3 /\left(\mathrm{Cr} / \mathrm{Cr}_{50}\right.\right.$ untuk usia) $]$. Koefisien 107,3 pada rumus tersebut dapat diinterpretasikan sebagai rerata LFG pada anak sehat, yang berarti kadar kreatinin serum pada anak tersebut sama dengan nilai median kreatinin serum untuk kelompok usianya. Namun, karena membutuhkan tabel rujukan untuk masing-masing usia, rumus ini dinilai tidak praktis seperti rumus Schwartz yang dimodifikasi, yang tidak membutuhkan tabel rujukan dan dapat dihitung secara langsung. Selain itu, rumus ini juga tidak memperhitungkan tinggi badan yang dinilai merupakan parameter yang representatif terhadap massa otot tubuh. ${ }^{17}$

Beberapa rumus berbasis kreatinin serum untuk mengestimasi LFG pada anak yang lebih kompleks juga dikembangkan (Tabel 3), termasuk rumus British Columbia Children's Hospital 1 (BCCH 1) yang melibatkan usia dan jenis kelamin, dan British Columbia Children's Hospital 2 (BCCH 2) yang melibatkan tinggi badan, usia, dan jenis kelamin. ${ }^{18}$ Selain itu, juga terdapat rumus yang dikembangkan oleh Gao et al. ${ }^{19}$ dan rumus LundMalmo $^{20}$ dengan kompleksitas yang sama. Keempat rumus tersebut, walaupun mempertimbangkan banyak parameter, merupakan rumus yang cukup kompleks dan sulit untuk digunakan secara bedside dan membutuhkan waktu perhitungan yang relatif lebih lama.

Tabel 3. Beberapa Rumus Perhitungan Estimasi LFG yang Juga Menggunakan Kadar Kreatinin Serum

\begin{tabular}{ll}
\hline \multicolumn{1}{c}{ Sumber } & \multicolumn{1}{c}{ Rumus } \\
\hline BCCH $1^{18}$ & $\ln (\mathrm{LFG})=1,18+0,0016 \times \mathrm{BB}+0,01 \times \mathrm{TB}+149,5 /(\mathrm{Cr} \times 88,4)-2141 /(\mathrm{Cr} \times 88,4)^{2}$ \\
BCCH $2^{18}$ & $\mathrm{LFG}=-61,56+5886 /(\mathrm{Cr} \times 88,4)+4,83 \times$ usia $(+10,02$ pada laki-laki $)$ \\
Gao et al. ${ }^{19}$ & $\mathrm{LFG}=0,68 \times \mathrm{TB} / \mathrm{Cr}-0,0008 \times(\mathrm{TB} / \mathrm{Cr}) 2+0,48 \times$ usia $(-21,53$ pada laki-laki, - \\
& $25,68$ pada perempuan $)$ \\
Lund-Malmo $^{20}$ & $\mathrm{LFG}=\exp [4,62-0,0112 \times \mathrm{Cr} \times 88,4-0,0124 \times$ usia $+0,339 \times \ln ($ usia $)]$ \\
\hline
\end{tabular}

Menentukan rumus yang paling sesuai untuk mengestimasi LFG berdasarkan kreatinin serum masih menjadi perdebatan. Rumus $\mathrm{BCCH} 1$ dikatakan cenderung mengestimasi LFG secara berlebih pada anak di atas usia dua tahun, sedangkan rumus BCCH 2 disusun berdasarkan data demografis suatu populasi kecil tertentu dan tidak dianjurkan untuk penggunaan luas. ${ }^{1}$ Rumus yang dikembangkan oleh Gao et al. ${ }^{19}$ dinilai cukup sesuai dengan rumus Pottel et al. ${ }^{10}$ untuk anak berusia 2 sampai 14 tahun, namun menunjukkan deviasi bila digunakan untuk remaja. Untuk anak dengan LFG normal atau lebih, secara umum sebagian besar rumus tersebut dinilai sebanding. Untuk anak dengan kelainan ginjal, penyakit ginjal kronik (PGK), dan pertumbuhan yang terhambat, rumus Schwartz yang dimodifikasi merupakan pilihan utama untuk mengestimasi nilai LFG pada anak secara sederhana. Salah satu keterbatasan pada berbagai rumus yang menggunakan nilai kreatinin serum adalah kecenderungan untuk mengestimasi fungsi ginjal secara berlebih pada anak dengan penurunan massa otot. ${ }^{1}$ 
Sebagian besar rumus untuk mengestimasi LFG pada anak yang berbasis kreatinin serum tidak dianjurkan untuk digunakan pada populasi usia di bawah dua tahun. Hal ini dikarenakan pada saat lahir, anak memiliki kadar kreatinin serum yang merefleksikan kadar kreatinin serum ibu (sekitar $0,70 \mathrm{mg} / \mathrm{dL}$ ), dan dalam satu bulan pertama kehidupan terjadi penurunan cepat dari sekitar $0,70 \mathrm{mg} / \mathrm{dL}$ menjadi $0,25 \mathrm{mg} / \mathrm{dL}$, yang kemudian mengalami peningkatan bertahap seiring dengan bertambahnya massa otot pada anak. ${ }^{21}$

Laju filtrasi glomerulus pada awalnya diestimasi dengan pengukuran klirens kreatinin atau dengan menggunakan rumus Schwartz, yaitu $[\mathrm{LFG}=\mathrm{k} \times \mathrm{T} / \mathrm{Cr}]$, dengan $\mathrm{k}$ merupakan konstanta, t merupakan tinggi badan dalam sentimeter $(\mathrm{cm})$ dan $\mathrm{Cr}$ merupakan kreatinin serum dalam $\mathrm{mg} / \mathrm{dL}$. Terkait konstanta yang digunakan, umumnya 0,33 pada bayi dengan berat badan lahir rendah yang berusia kurang dari 1 tahun, 0,45 pada bayi aterm yang berusia kurang dari 1 tahun, 0,55 pada anak berusia 1 sampai 12 tahun, 0,55 pada perempuan yang berusia 13 sampai 21 tahun, dan 0,70 pada laki-laki yang berusia 13 sampai 21 tahun. ${ }^{22}$ Sesuai dengan perkembangan, didapatkan bahwa konstanta 0,413 dinilai lebih sesuai untuk mengestimasi LFG pada populasi anak dan remaja, sehingga dikembangkan rumus Schwartz yang dimodifikasi, yaitu [LFG $=0,413 \mathrm{x} \mathrm{T} / \mathrm{Cr}$ ], yang kini dianut sebagai rumus sederhana pilihan untuk mengestimasi LFG pada sebagian besar fasilitas kesehatan anak di dunia. ${ }^{3}$

\section{Rumus LFG Berbasis Sistatin C}

Penentuan LFG menggunakan kadar sistatin $\mathrm{C}$ diduga dapat menjembatani beberapa keterbatasan yang didapatkan pada rumus penentuan LFG yang menggunakan kreatinin serum. Sistatin C merupakan suatu protein kecil yang difiltrasi secara bebas oleh glomerulus dan tidak dipengaruhi oleh usia, jenis kelamin, dan massa otot secara signifikan. Akan tetapi, sistatin $\mathrm{C}$ dapat dipengaruhi oleh penggunaan obat-obatan tertentu, seperti steroid, pada pasien dengan inflamasi, kelainan hormon tiroid, dan pasien transplantasi ginjal. ${ }^{23}$ Beberapa rumus yang menggunakan sistatin $\mathrm{C}$ dalam mengestimasi LFG telah dikembangkan selama beberapa tahun terakhir, tetapi tidak didapatkan lebih superior dibandingkan rumus yang berbasis kreatinin serum. ${ }^{24}$ Rumus yang berbasis sistatin $\mathrm{C}$ dinilai lebih akurat dibandingkan dengan rumus yang berbasis kreatinin serum dalam menentukan LFG pada anak dengan usia di bawah 2 tahun. ${ }^{25}$ Beberapa jenis rumus untuk mengestimasi LFG yang berbasis sistatin $\mathrm{C}$ dicantumkan pada Tabel 4.

Tabel 4. Beberapa Rumus untuk Mengestimasi LFG pada Anak Menggunakan Kadar Sistatin C

\begin{tabular}{|c|c|}
\hline Sumber & Rumus LFG \\
\hline Rule et $_{\text {al. }}{ }^{26}$ & $\mathrm{LFG}=76,6 \times \mathrm{CysC}^{-1,16}$ \\
\hline Filler dan Lepage ${ }^{27}$ & $\mathrm{LFG}=91,62 \times \mathrm{CysC}^{-1,123}$ \\
\hline Zappitelli et al. ${ }^{28}$ & $\mathrm{LFG}=75,94 \times \mathrm{CysC}^{-1,17}$ \\
\hline
\end{tabular}

Pada Tabel 4 dapat dilihat bahwa sebagian besar rumus yang diformulasikan untuk mengestimasi LFG berdasarkan kadar sistatin C memiliki kemiripan dalam hal adanya hubungan berbanding terbalik antara LFG dan sistatin C. Nilai rujukan untuk sistatin C bervariasi antara 0,50 dan $1,50 \mathrm{mg} / \mathrm{L}$. Perbedaan berbagai rumus yang tersedia terutama lebih jelas terlihat pada kadar sistatin $\mathrm{C}$ yang lebih rendah, yang dapat menjadi tanda dibutuhkannya model multivariabel untuk meneliti faktor-faktor demografik independen seperti usia, jenis kelamin, tinggi badan, berat badan, dan penanda endogen lain seperti kreatinin serum untuk dapat dengan lebih akurat menjelaskan hubungan antara LFG dan sistatin C. ${ }^{29}$

Alasan terdapatnya beberapa rumus yang berbeda untuk mengestimasi LFG dengan menggunakan sistatin $\mathrm{C}$ adalah karena sebelumnya belum didapatkan adanya kalibrator 
sistatin $\mathrm{C}$ secara internasional dan tidak adanya ekuivalensi untuk hasil yang diperoleh dengan metode pemeriksaan sistatin $\mathrm{C}$ yang berbeda. Metode pemeriksaan sistatin $\mathrm{C}$ dengan cara turbidimetrik dan nefelometrik menunjukkan hasil yang bervariasi, karena metode nefelometrik dinilai lebih akurat dalam mengestimasi LFG. Saat ini, karena sudah terdapat pemeriksaan rujukan yang tersertifikasi untuk sistatin $\mathrm{C}$, rumus terbaru yang paling sederhana adalah rumus Caucasian, Asian, Pediatric, Adult (CAPA), yaitu [LFG $=130 \mathrm{x} \mathrm{CysC}^{-1,069} \mathrm{x}$ usia $\left.^{-0,117}-7\right]$, yang diketahui juga dapat digunakan pada populasi anak. Rumus yang telah dievaluasi pada populasi anak di Belanda dan Swedia tersebut menunjukkan ketepatan sekitar $75-80 \%$, dan masih terdapat ruang untuk perbaikan di masa depan. ${ }^{30}$

Terdapat juga beberapa rumus untuk mengestimasi LFG yang menggabungkan antara kreatinin serum dan sistatin $\mathrm{C}$ bersama dengan variabel demografik, termasuk tinggi badan, berat badan, usia, dan jenis kelamin, dan/atau variabel klinis, termasuk riwayat transplantasi ginjal atau kondisi kesehatan tertentu. Namun, rumus yang diformulasikan cenderung menjadi lebih kompleks. Beberapa contohnya dirangkum dalam Tabel 5.

Tabel 5. Beberapa Rumus Berbasis Sistatin C dan Kreatinin Serum Untuk Mengestimasi Lfg

\begin{tabular}{ll}
\hline \multicolumn{1}{c}{ Sumber } & \multicolumn{1}{c}{ Rumus } \\
\hline Zappitelli et al. $^{28}$ & $\mathrm{LFG}=(43,82 \times \exp (0,003 \times \mathrm{TB})) /\left(\mathrm{CysC}^{-0,635} \times \mathrm{Cr}^{0,547}\right)$ \\
& $\mathrm{x} 1,165$ pada transplantasi ginjal \\
& $\mathrm{x} 1,57 \mathrm{Scr}{ }^{0,925}$ pada spina bifida \\
& $\mathrm{LFG}=0,42 \times(\mathrm{TB} / \mathrm{Cr})-0,04 \times(\mathrm{TB} / \mathrm{Cr})^{2}-14,5 \times \mathrm{CysC}+0,69 \times$ usia \\
& $+18,25$ untuk perempuan \\
& $+21,88$ untuk laki-laki \\
Penelitian Chronic Kidney Disease in in $^{31}$ & $\mathrm{LFG}=39,8 \times(\mathrm{TB} / \mathrm{Cr})^{0,456} \times(1,8 / \mathrm{CysC})^{0,418} \times(30 / \mathrm{BUN})^{0,079} \mathrm{x}$ \\
Children $(\mathrm{CKiD})^{32}$ & $(\mathrm{~TB} / 1,4)^{0,179}$ \\
\hline
\end{tabular}

\section{Pembahasan}

Pengukuran LFG secara langsung dapat dilakukan melalui evaluasi penanda filtrasi eksogen, termasuk inulin yang merupakan standar baku emas saat ini, maupun penanda eksogen lainnya seperti ioheksol, ${ }^{51} \mathrm{Cr}$-EDTA, ${ }^{99 \mathrm{~m}} \mathrm{Tc}-\mathrm{DTPA}$, iotalamat, dan sebagainya. Akan tetapi, berbagai metode pengukuran LFG dengan menggunakan penanda filtrasi eksogen membutuhkan fasilitas yang lengkap dan biaya yang tidak terjangkau, yang membuatnya tidak sesuai untuk diterapkan pada praktik klinis sehari-hari.

Estimasi LFG pada anak dapat dilakukan dengan menggunakan rumus yang memperhitungkan penanda filtrasi endogen serta elemen demografis seperti tinggi badan, usia, dan jenis kelamin, yang relatif lebih sederhana. Namun, salah satu tantangan yang penting untuk dipertimbangkan adalah kapan masing-masing rumus dapat digunakan secara tepat. Rumus yang berbasis sistatin $\mathrm{C}$ lebih dipilih dibandingkan dengan yang berbasis kreatinin serum pada pasien dengan penurunan massa otot, misalnya pasien dengan Duchenne muscular dystrophy, pasien dengan anoreksia, pasien onkologi, pasien dengan keterbatasan gerak ekstremitas, dan sebagainya, karena penggunaan rumus berbasis kreatinin serum pada pasien dengan kondisi klinis tersebut dapat mengestimasi LFG secara berlebih. Namun, belum diketahui secara jelas apakah rumus berbasis sistatin $\mathrm{C}$ memiliki keunggulan dibandingkan dengan rumus berbasis kreatinin serum pada anak dengan kondisi klinis lainnya. Selain itu, karena biaya yang dibutuhkan untuk pemeriksaan sistatin C diperkirakan 
delapan kali lebih tinggi dibandingkan dengan pemeriksaan kreatinin serum, evaluasi sistatin $\mathrm{C}$ juga tidak direkomendasikan untuk dilakukan secara rutin.

Dari sudut pandang praktik klinis sehari-hari, salah satu fungsi terpenting rumus estimasi LFG adalah agar dapat membedakan anak dengan LFG normal (>75 mL/menit/1,73 $\left.\mathrm{m}^{2}\right)$ dari anak dengan LFG abnormal. Rumus Schwartz yang dimodifikasi dianggap cukup sederhana dan dapat mencapai tujuan tersebut, kecuali apabila kadar kreatinin serum menjadi sangat rendah akibat kondisi kesehatan tertentu pada pasien. Pada beberapa pengecualian tersebut, rumus sistatin $\mathrm{C}$ univariat dapat digunakan untuk menggantikan rumus berbasis kreatinin serum yang sederhana untuk beberapa pengecualian tersebut. Akan tetapi, pada kondisi yang membutuhkan tingkat keakuratan yang tinggi, menggunakan rumus yang melibatkan kadar kreatinin serum dan sistatin $\mathrm{C}$ memiliki ketepatan yang lebih tinggi dalam mengestimasi LFG.

Di masa depan, penelitian lebih lanjut untuk mengestimasi fungsi ginjal dapat menghasilkan rumus estimasi LFG yang baru, menggunakan biomarker seperti mikroglobulin B-2 atau $\beta$-trace protein (BTP). Beberapa penelitian telah mengemukakan bahwa BTP lebih superior dibandingkan kreatinin serum dan merupakan alternatif dari sistatin $\mathrm{C}$ dalam mendeteksi penurunan LFG yang ringan pada anak, walaupun dikatakan tidak superior dibandingkan dengan rumus Schwartz yang dimodifikasi. Rumus spesifik yang berdasarkan BTP, kreatinin serum, dan tinggi badan masih sedang dikembangkan, akan tetapi masih dibutuhkan validasi eksternal untuk menentukan apakah rumus baru tersebut dapat diterapkan secara luas. Biaya dan ketersediaan suatu penanda juga memegang peranan penting untuk menentukan apakah suatu rumus dapat diterapkan pada praktik klinis sehari-hari.

\section{Kesimpulan}

Menentukan fungsi ginjal dengan cara yang praktis sangat penting untuk membantu penilaian klinis. Oleh karena itu, penilaian estimasi LFG seringkali dilakukan menggunakan rumus yang berbasis kreatinin serum. Salah satu pilihan rumus yang kini direkomendasikan untuk praktik klinis sehari-hari adalah rumus Schwartz yang dimodifikasi, karena dinilai paling sederhana, akurat, tidak invasif, dan terjangkau.

\section{Daftar Pustaka}

1. Pottel H. Measuring and estimating glomerular filtration rate in children. Pediatr Nephrol. 2017;32:249-63.

2. Schwartz GJ, Haycock GB, Edelmann Jr CM, Spitzer A. A simple estimate of glomerular filtration rate in children derived from body length and plasma creatinine. Pediatrics. 1976;58:259-63.

3. Schwartz GJ, Munoz A, Schneider MF, Mak RH, Kaskel F, Warady BAFS. New equations to estimate GFR in children with CKD. J Am Soc Nephrol. 2009;20:629-37.

4. Lunn A. Automatic reporting of creatinine-based estimated glomerular filtration rate in children: is this feasible? EMJ Nephrol. 2016;4:106-112.

5. Pottel H, Dubourg L, Goffin K, Delanaye P. Alternatives for the bedside Schwartz equation to estimate glomerular filtration rate in children. Adv Chronic Kidney Dis. 2018;25:57-66.

6. Alatas H, Ambarsari CG. Anatomi dan fisiologi ginjal. Dalam: Rachmadi D, Sekarwana N, Hilmanto D, Garna H, penyunting. Buku Ajar Nefrologi Anak. Edisi ke-3. Jakarta: Badan Penerbit Ikatan Dokter Anak Indonesia; 2017. h. 38-9.

7. Stevens LA, Levey AS. Measured GFR as a confirmatory test for estimated GFR. J Am Soc Nephrol. 2009;20:2305-13.

8. Schwartz GJ, Work DF. Measurement and estimation of GFR in children and adolescents. Clin J Am Soc Nephrol. 2009;4:1832-43.

9. Soveri I, Berg UB, Bjork J, Elinder CG, Grubb A, Mejare I, et al. Measuring GFR: a systematic review. Am J Kidney Dis. 2014;64:411-24.

10. Pottel H, Mottaghy FM, Zaman Z, Martens F. On the relationship between glomerular filtration rate and serum creatinine in children. Pediatr Nephrol. 2010;25:927-34. 
11. Brodehl J, Gellissen K, Weber H. Postnatal development of tubular phosphate reabsorption. Clin Nephrol. 1982;17:163-71.

12. Piepsz A, Tondeur M, Ham H. Escaping the correction for body surface area when calculating glomerular filtration rate in children. Eur J Nucl Med Mol Imaging. 2008;35:1669-72.

13. Delanaye P, Schaeffner E, Ebert N, Cavalier E, Mariat C, Krzesinski JM, et al. Normal reference values for glomerular filtration rate: what do we really know? Nephrol Dial Transplant. 2012;27:2664-72.

14. Mian AN, Schwartz GJ. Measurement and estimation of glomerular filtration rate in children. Adv Chronic Kidney Dis. 2017;24:348-56.

15. Muhari-Stark E, Burckart GJ. Glomerular filtration rate estimation formulas for pediatric and neonatal use. J Pediatr Pharmacol Ther. 2018;23:424-31.

16. Pottel H, Hoste L, Martens F. A simple height-independent equation for estimating glomerular filtration rate in children. Pediatr Nephrol. 2012;27:973-79.

17. Pottel H, Hoste L, Delanaye P. Abnormal glomerular filtration rate in children, adolescents and young adults starts below $75 \mathrm{~mL} / \mathrm{min} / 1.73 \mathrm{~m}^{2}$. Pediatr Nephrol. 2015;30:821-8.

18. Mattman A, Eintracht S, Mock T, Schick G, Seccombe DW, Hurley RM,et al. Estimating pediatric glomerular filtration rates in the era of chronic kidney disease staging. J Am Soc Nephrol. 2006;17:487-96.

19. Gao A, Cachat F, Faouzi M, Bardy D, Mosig D, Meyrat BJ, dkk. Comparison of the glomerular filtration rate in children by the new revised Schwartz formula and a new generalized formula. Kidney Int. 2013;83:524-30.

20. Nyman U, Bjork K, Lindstrom V, Grubb A. The Lund-Malmo creatinine-based glomerular filtration rate prediction equation for adults also performs well in children. Scand J Clin Lab Invest. 2008;68:568-76.

21. Selistre L, De Souza V, Cochat P, Ferreira AIC, Hadj-Aissa A, Ranchin B,et al. GFR estimation in adolescents and young adults. J Am Soc Nephrol. 2012;23:989-96.

22. Noer MS. Glomerulonefritis. Dalam: Rachmadi D, Sekarwana N, Hilmanto D, Garna H, penyunting. Buku Ajar Nefrologi Anak. Edisi ke-3. Jakarta: Badan Penerbit Ikatan Dokter Anak Indonesia; 2017. h. 197.

23. Andersen TB, Eskild-Jensen A, Frokiaer J, Brochner-Mortensen J. Measuring glomerular filtration rate in children: can cystatin C replace established methods? A review. Pediatr Nephrol 2009;24:929-41.

24. Bacchetta J, Cochat P, Rognant N, Ranchin B, Hadj-Aissa A, Dubourg L. Which creatinine and cystatin C equations can be reliably used in children? Clin J Am Soc Nephrol. 2011;6:552-60.

25. Abitbol CL, Seeherunvong W, Galarza MG, Katsoufis C, Francoeur D, Defreitas M,et al. Neonatal kidney size and function in preterm infants: what is a true estimate of glomerular filtration rate? J Pediatr. 2014;164:1026-31.

26. Rule AD, Bergstralh EJ, Slezak JM, Bergert J, Larson TS. Glomerular filtration rate estimated by cystatin C among different clinical presentations. Kidney int. 2006;69:399-405.

27. Filler G, Lepage N. Should the Schwartz formula for estimation of GFR be replaced by cystatin C formula? Pediatr Nephrol. 2003;18:981-85.

28. Zappitelli M, Parvex P, Joseph L, Paradis G, Grey V, Lau S, et al. Derivation and validation of cystatin Cbased prediction equations for GFR in children. Am J Kidney Dis. 2006;48:221-30.

29. Fadrowski JJ, Neu AM, Schwartz GJ, Furth SL. Pediatric GFR estimating equations applied to adolescents in the general population. Clin J Am Soc Nephrol. 2011;6:1427-35.

30. Grubb A, Horio M, Hansson LO, Bjork J, Nyman U, Flodin M,et al. Generation of a new cystatin C-based estimating equation for glomerular filtration rate by use of 7 assays standardized to the international calibrator. Clin Chem. 2014;60:974-86.

31. Chehade H, Cachat F, Jannot AS, Meyrat BJ, Mosig D, Bardy D, et al. New combined serum creatinine and cystatin C quadratic formula for GFR assessment in children. Clin J Am Soc Nephrol. 2014;9:54-63.

32. Schwartz GJ, Schneider MF, Maier PS, Moxey-Mims M, Dharnidharka VR, Warady BA, et al. Improved equations estimating GFR in children with chronic kidney disease using an immunoephelometric determination of cystatin C. Kidney Int. 2012;82:445-53. 